\title{
Poziom nakładów materialnych a wyniki ekonomiczne gospodarstw indywidualnych
}

\section{Wstęp}

W ostatnich latach, głównie ze względu na wprowadzenie zasad gospodarki rynkowej, uruchomienie procesu transformacji własnościowej oraz wejście Polski do Unii Europejskiej, wzrosła konieczność zachowania konkurencyjności funkcjonowania gospodarstw indywidualnych. Potencjał produkcyjny rolnictwa wyznaczony jest przede wszystkim przez ilość i jakość czynników produkcji oraz przez sposób ich połączenia w procesie wytwarzania. W rzeczywistości gospodarczej układy strukturalne czynników wytwórczych dają różne efekty ekonomiczno-produkcyjne, mierzone stopą transformacji nakładów. Każdy racjonalny system gospodarczy dąży przede wszystkim do systematycznego podnoszenia relacji efekty/nakłady i zmierza do zmniejszenia łącznych nakładów na jednostkę wytworzonej produkcji. Można stwierdzić, że racjonalność podsystemu gospodarki, jakim jest rolnictwo w dużej mierze odzwierciedlona jest przez efektywność stosowanych technik wytwórczych [Gołaś 1999].

Produkcja jest rezultatem nakładów ponoszonych przez producenta. Przez nakłady rozumiemy sumę pracy żywej i uprzedmiotowionej, zużytej przez producenta $\mathrm{w}$ procesie produkcji w celu wytworzenia określonego produktu i/lub usługi. Efektem ponoszenia nakładów są kategorie produkcyjne i wynikowe. Pozwalają one ocenić wykorzystanie zaangażowanych $\mathrm{w}$ proces produkcji czynników wytwórczych, np. poprzez wydajność pracy, efektywność zasobów ziemi oraz kapitału [Ziętara 2000, Klepacki 2002, Wasilewski 2003a]. Nakłady pracy uprzedmiotowionej, zwane często nakładami materialnymi, składają się $\mathrm{z}$ nakładów środków trwałych (amortyzacja) i obrotowych (materiały). Są to więc nakłady pracy ludzkiej poniesione dawniej i zmaterializowane w produktach [Adamowski 1981, Rychlik 1983]. Dwie cechy charakteryzują nakłady: materialny charakter $\mathrm{i}$ zastosowanie $w$ produkcji. Cechy te wyodrębniają nakłady od innych pokrewnych kategorii. Wydatki takie jak podatek, odsetki od zadłużeń, czynsze dzierżawne, kary, grzywny itp. nie są nakładami, gdyż nie mają charakteru materialnego [Urban 1981]. Ponoszenie nakładów wymaga źródeł 
finansowania własnych oraz $\mathrm{w}$ razie potrzeby obcych, krótko- i długoterminowych, które powinny być efektywne i ekonomicznie uzasadnione [Wasilewski 2003b, Wasilewski 2004].

Według zasad kwalifikacji nakładów materialnych przez Instytut Ekonomiki Rolnictwa i Gospodarki Żywnościowej (IERiGŻ) w gospodarstwach prowadzących rachunkowość, obejmują one [Wyniki rachunkowości 2001]:

- nasiona i sadzeniaki własne i dokupione, nawozy mineralne, środki ochrony roślin oraz inne nakłady związane $\mathrm{z}$ uprawą (obornika własnego oraz słomy się nie liczy),

- pasze własne i dokupione, stado obrotowe oraz inne nakłady na produkcję zwierzęca,

- naprawy i konserwacje budynków, melioracji oraz maszyn i narzędzi rolniczych,

- eksploatację pojazdów samobieżnych na cele produkcyjne,

- amortyzację środków trwałych, jak: budynki, melioracje, maszyny i narzędzia rolnicze,

- nakłady związane z prowadzeniem gospodarstwa, jak: opał, energia elektryczna, materiały pędne, koszty przemiału, donajmu maszyn itp.,

- straty w inwentarzu żywym, tzn. wartość sztuk padłych, które figurowały na początku roku w bilansie otwarcia, bądź sztuk padłych stada podstawowego, pochodzących z zakupu,

- utrzymanie koni roboczych własnych, które wydzielono z nakładów na produkcję zwierzęcą.

Celem badań było określenie zależności wyników ekonomicznych od poziomu nakładów materialnych $\mathrm{w}$ indywidualnych gospodarstwach rolniczych. Do pomiaru efektywności gospodarstw przyjęto kategorie: dochodu rolniczego, produkcji końcowej netto i produkcji czystej. $Z$ ich wykorzystaniem określono społeczną wydajność pracy, jako relację produkcji czystej do liczby jednostek pełnosprawnych siły roboczej (jpsr) ${ }^{1}$, oraz kategorię ekonomicznej wydajności pracy, jako relacje produkcji czystej do nakładów pracy w roboczogodzinach (rbh). Ponadto, obliczono rentowność sprzedaży, jako relację dochodu rolniczego do wartości przychodów ze sprzedaży. Wszystkie wielkości wartościowe zostały wyrażone w cenach bieżących. Badaniem objęto 95 gospodarstw indywidualnych, położonych w regionie środkowozachodnim, według systemu regionalizacji IERiGŻ, który obejmuje województwa wielkopolskie i kujawsko-pomorskie. Makroregion środkowozachodni charakteryzuje się wysokim w skali kraju poziomem cech organizacyjno-technicznych rolnictwa. Gospodar-

\footnotetext{
'Przyjęto następujące współczynniki przeliczeniowe (wsp. p.) osób młodocianych, osób w wie$\mathrm{ku}$ produkcyjnym i poprodukcyjnym (opartych na kryterium fizjologicznym), przyjmując za podstawę dane źródłowe $\mathrm{z}$ rachunkowości IERiGŻ: do 14 lat - wsp. p. 0,4, 15-60 lat - wsp. p. 0,9 , powyżej 60 lat - wsp. p. 0,4 .
} 
stwa położone w tym makroregionie mają bowiem wysoką intensywność produkcji i organizacji oraz najwyższe, według wyników rachunkowości, wyniki produkcyjno-ekonomiczne [Wyniki rachunkowości 2001]. Do badań wybrano wszystkie gospodarstwa prowadzące nieprzerwanie rachunkowość rolną w latach 1997-2000. Analizą zostały objęte gospodarstwa o powierzchni powyżej 15 ha użytków rolnych. Jako kryterium klasyfikacji gospodarstw wykorzystano poziom nakładów materialnych $\mathrm{w}$ przeliczeniu na jeden hektar użytków rolnych (UR). Wydzielono następujące grupy gospodarstw: pierwsza (25\% gospodarstw) charakteryzuje się najniższym poziomem nakładów materialnych, druga - średnim ( $50 \%$ gospodarstw), trzecia - najwyższym ( $25 \%$ gospodarstw). Analizując uzyskane wielkości ekonomiczne wykorzystano zatem podział gospodarstw indywidualnych na pierwszą (I), drugą (II) i trzecią (III) grupę.

\section{Wyniki badań}

$\mathrm{Na}$ rysunku 1 przedstawiono kształtowanie się dochodu rolniczego w zależności od poziomu nakładów materialnych. W większości analizowanych lat (z wyjątkiem 1998 roku) pod względem dochodu rolniczego dominowała grupa gospodarstw o najwyższym poziomie nakładów materialnych. Przewaga tej grupy była szczególnie widoczna w 1999 roku, bowiem dochód rolniczy wynosił $1407,1 \mathrm{zt} / \mathrm{ha}$ UR, podczas gdy w grupie gospodarstw o nakładach najniższych był o $68,1 \%$ niższy. Najwyższy poziom dochodowości ziemi w analizowanych latach wystapił w trzeciej grupie gospodarstw w 2000 roku, wynosił $1522,7 \mathrm{zł} / \mathrm{ha}$ UR i był wyższy o $136,6 \%$ niż w grupie pierwszej i o $26,7 \%$ niż w grupie drugiej. Jednocześnie jedynie $w$ trzeciej grupie gospodarstw zauważalna była tendencja rosnąca dochodowości ziemi w latach 1998-2000. Najniższy poziom dochodowości ziemi wystapił w pierwszej grupie gospodarstw, która charakteryzowała się jednocześnie największąjej stabilnością.

W przypadku produktywności ziemi zależności $\mathrm{W}$ stosunku do ponoszonych nakładów materialnych były zbliżone jak przy wskaźniku dochodowości ziemi (rys. 2). Różnice w produktywności ziemi pomiędzy analizowanymi grupami gospodarstw były jednak mniejsze. We wszystkich analizowanych latach najwyższą produktywnością ziemi charakteryzowały się gospodarstwa o najwyższych nakładach materialnych. W 2000 roku produktywność ta była wyższa o $89,1 \%$ w porównaniu z grupą pierwsza, podczas gdy różnica na korzyść gospodarstw z grupy drugiej wynosiła $47,6 \%$. Najniższą i jednocześnie najbardziej stabilną w czasie produktywnością ziemi charakteryzowały się gospodarstwa o najniższym poziomie nakładów materialnych. Jedynie w trzeciej grupie gospodarstw wystapiła tendencja rosnąca produktywności ziemi i w latach 1998-2000 wynosiła 118,6\%. We wszystkich grupach gospodarstw w latach 


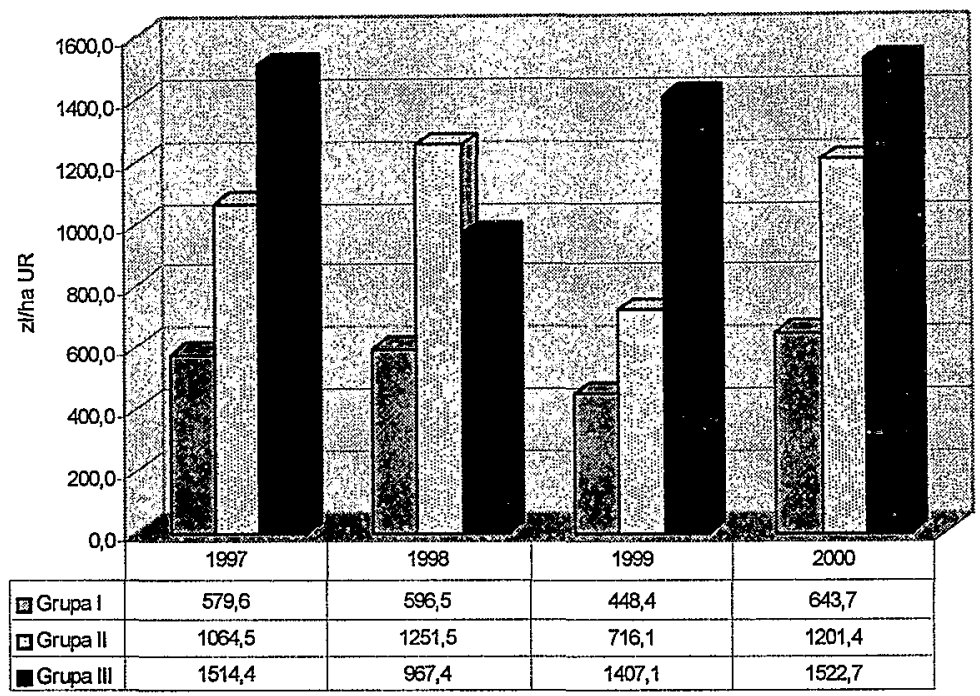

\section{Rysunek 1}

Dochód rolniczy (zł/ha UR) według nakładów materialnych

Żródło: Badania własne.

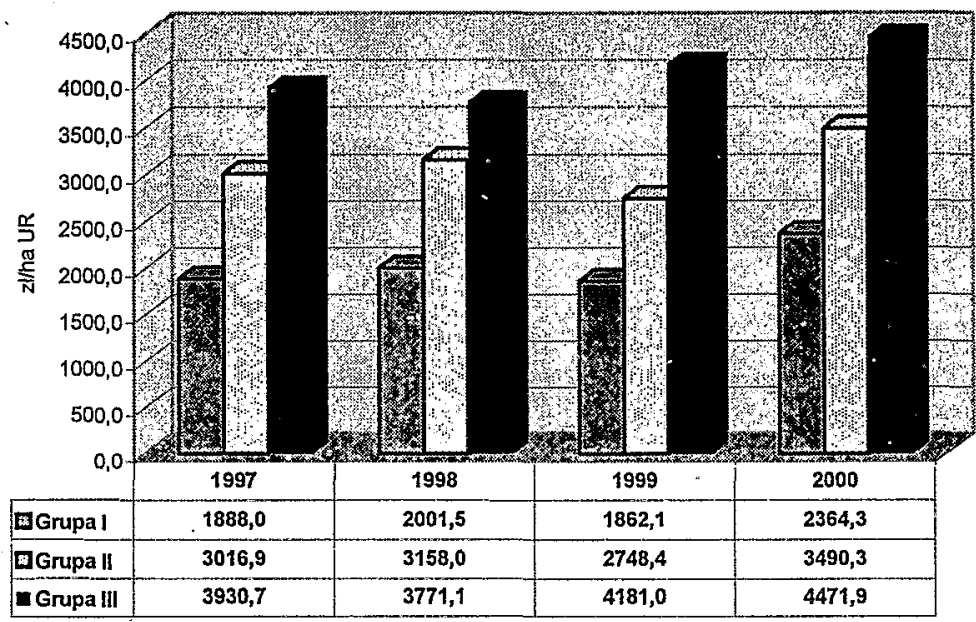

\section{Rysunek 2}

Produkcja końcowa netto (zł/ha UR) według nakładów materialnych Źródło: Badania własne. 
1999-2000 wystąpił wzrost produktywności ziemi, najbardziej widoczny $\mathrm{w}$ drugiej grupie gospodarstw (o 127,0\%).

Na rysunku 3 przedstawiono kształtowanie się społecznej wydajności pracy. W grupie trzeciej we wszystkich analizowanych latach społeczna wydajność pracy była najwyższa (w najmniejszym stopniu w 1998 roku, a najbardziej w 1999 roku). W 2000 roku różnica na korzyść trzeciej i drugiej grupy gospodarstw w stosunku do grupy pierwszej wynosiła odpowiednio $63,2 \%$ i $26,8 \%$. Najwyższy poziom społecznej wydajności pracy wystapił w trzeciej grupie w 2000 roku, a najniższy w grupie pierwszej w 1999 roku. Chociaż zasoby siły roboczej wyrażone w jpsr nie informują o intensywności jej wykorzystania, to jednak można przypuszczać, że wykorzystywane są tym efektywniej, im większe nakłady materialne są angażowane $w$ procesie produkcji. Potwierdzeniem tych zależności może być analiza ekonomicznej wydajności pracy w zależności od poniesionych nakładów materialnych. Gospodarstwa o najwyższym poziomie nakładów materialnych charakteryzowały się bowiem także najwyższą ekonomiczną wydajnością pracy, przy czym ich przewaga nad pozostałymi gospodarstwami była nieznacznie niższa w wypadku niż społecznej wydajności pracy.(rys. 4). Zależność ta widoczna jest zwłaszcza w 2000 roku, w którym gospodarstwa $\mathrm{z}$ trzeciej grupy w stosunku do grupy drugiej i pierwszej miały ekonomiczną wydajność pracy wyższą odpowiednio o $35,2 \%$ i $36,4 \%$. Zatem bardzo zbliżony był poziom ekonomicznej wydajności pracy w pierwszej i drugiej grupie gospodarstw.

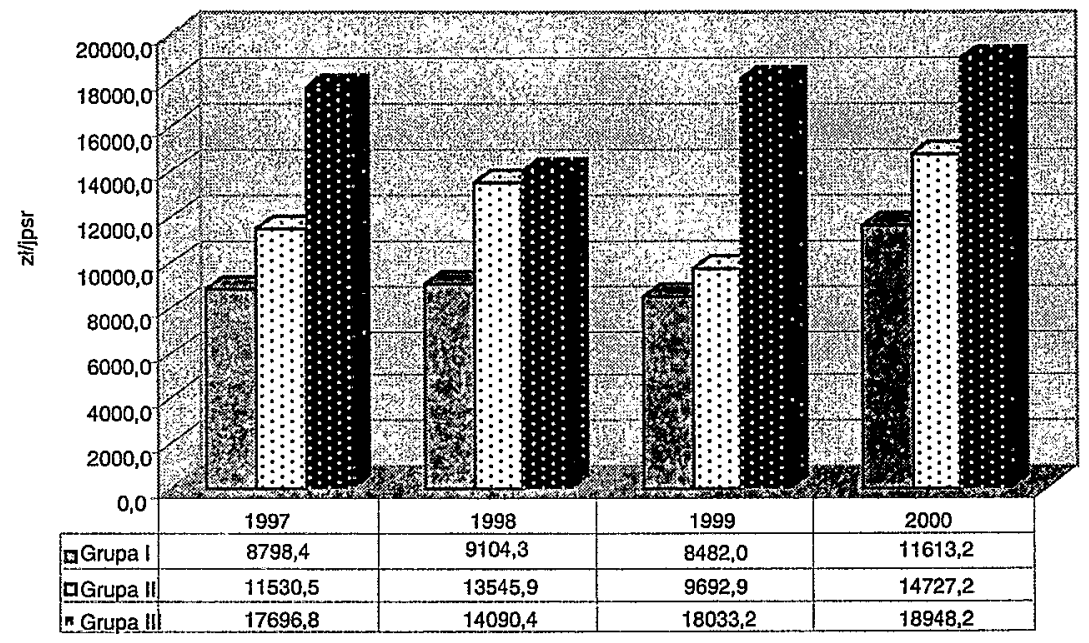

Rysunek 3

Społeczna wydajność pracy (produkcja czysta $w$ złłjpsr) według nakładów materialnych Źródło: Badania własne. 


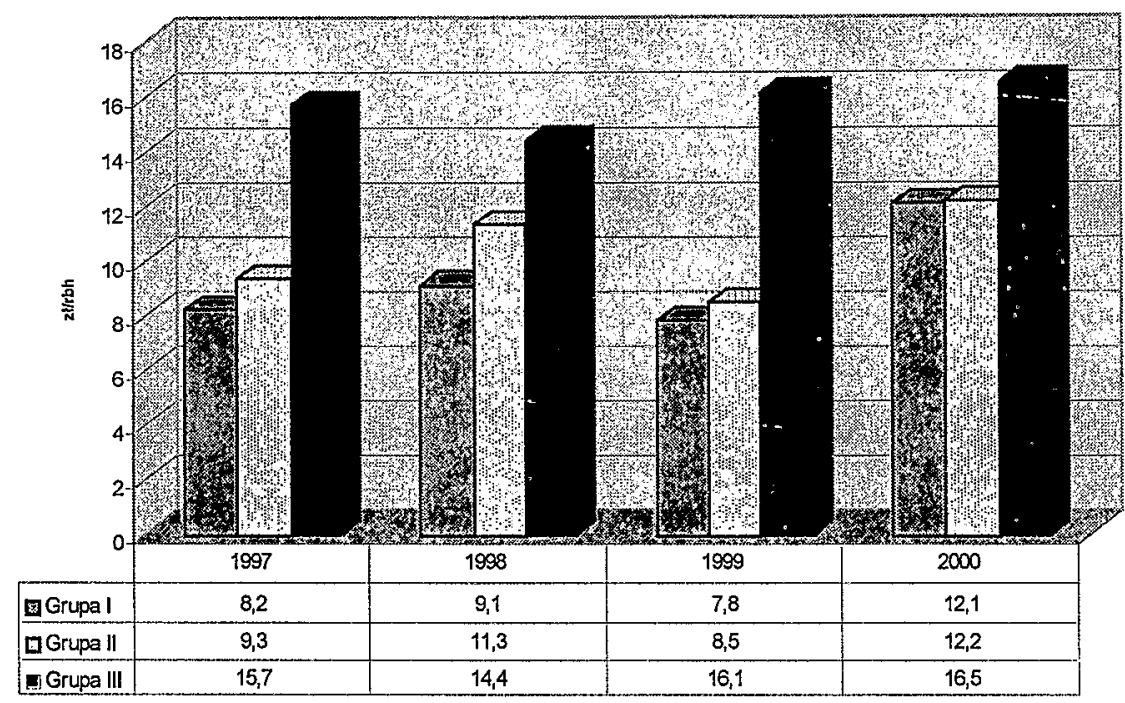

\section{Rysunek 4}

Ekonomiczna wydajność pracy (produkcja czysta w zł/rbh) według nakładów materialnych

Źródło: Badania własne.

Świadczyć to może o tym, że dopiero odpowiednio duża koncentracja nakładów materialnych pozwala na uzyskanie wysokiej ekonomicznej wydajności pracy. W żadnej z grup gospodarstw nie wystapiła jednorodna rosnąca lub malejąca tendencja ekonomicznej wydajności pracy w czasie, w ujęciu dynamicznym. Może być to spowodowane różnorodnością czynników wpływających na wydajność pracy w gospodarstwach w poszczególnych latach.

$\mathrm{Na}$ rysunku 5 przedstawiono kształtowanie się rentowności sprzedaży określonej relacją dochodu rolniczego do przychodów ze sprzedaży w zależności od poziomu nakładów materialnych. W większości analizowanych lat (z wyjątkiem 1999 roku) pod względem poziomu tego wskaźnika dominowały gospodarstwa z grupy drugiej, zwłaszcza w 1998 roku, w którym wskaźnik ten wynosił $39,2 \%$, i był najwyższy w analizowanym okresie. Najniższa rentowność sprzedaży wystapiła także w tym roku w trzeciej grupie gospodarstw i wynosiła jedynie $18,8 \%$, tj. o 24,4 pkt procentowych mniej niż w grupie drugiej i o 11,0 pkt procentowych mniej niż w grupie pierwszej. Nieznaczna przewaga trzeciej grupy gospodarstw nad pozostałymi była widoczna jedynie w 1999 roku. Można zatem stwierdzić, że gospodarstwa o najwyższym poziomie nakładów materialnych, charakteryzujące się na ogół najwyższą produktywnością i dochodowością ziemi oraz wydajnością pracy, rentowność sprzedaży miały relatywnie niższą. Jedną z przyczyn niższej rentowności sprzedaży 


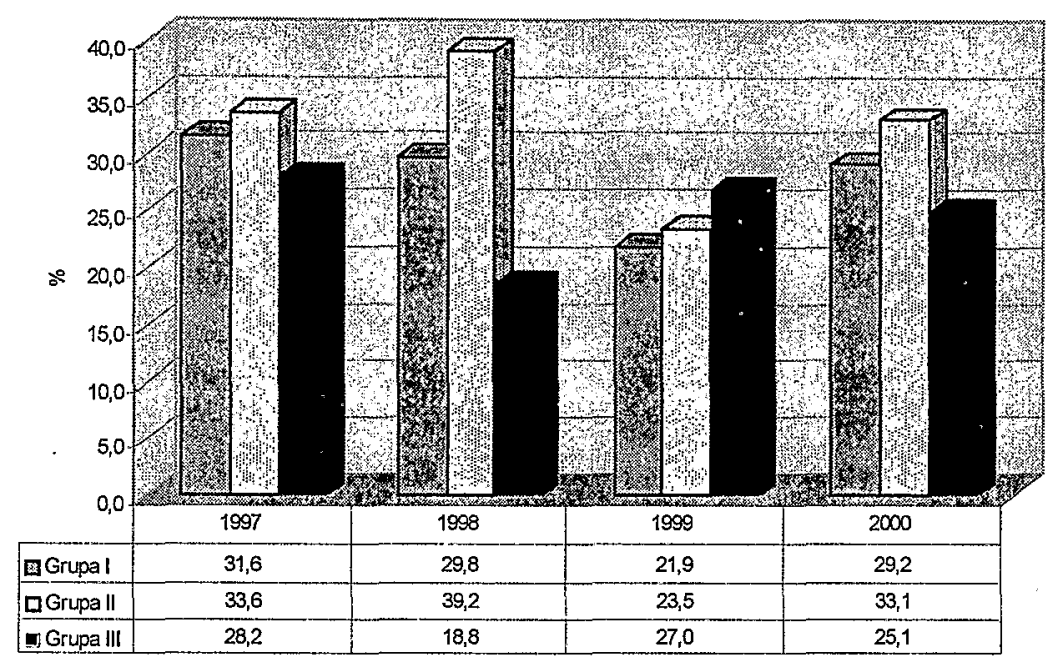

\section{Rysunek 5}

Rentowność sprzedaży (\%) według nakładów materialnych

Żródło: Badania własne.

może być spadek efektywność kolejnej jednostki nakładu, wraz ze zwiększaniem ich poziomu. Jest to zwiazzane $\mathrm{z}$ wykorzystywaniem $\mathrm{w}$ większym stopniu środków do produkcji z zakupu, co zwiększa wielkości wymienionych wskaźników efektywnościowych, ale jednocześnie może przyczyniać się do nieznacznie niższej rentowności sprzedaży w tej grupie gospodarstw. Ponadto, rentowność sprzedaży określa efektywność zwrotu poniesionych kosztów produkcji, istotna jest także wartość łączna dochodu uzyskiwana w skali gospodarstwa jako całości. Kwota łączna dochodu wyznacza bowiem możliwości rozwojowe gospodarstwa, chociaż należy dążyć do jak najwyższej rentowności (efektywności) jednostkowej.

\section{Podsumowanie}

W opracowaniu przedstawiono analizę zależności wyników ekonomicznych od poziomu koncentracji nakładów materialnych w indywidualnych gospodarstwach rolniczych. Na podstawie przeprowadzonych badań sformułowano następujące wnioski końcowe.

1. Najwyższą dochodowością ziemi charakteryzowały się gospodarstwa o największych nakładach materialnych, podczas gdy w grupie gospo- 
darstw o najniższym poziomie tych nakładów dochodowość była zdecydowanie najmniejsza. W przypadku produktywności ziemi zależności były zbliżone, jak występujące przy ocenie jej dochodowości. Gospodarstwa o najwyższych nakładach materialnych charakteryzowały się ponadto tendencją rosnącą produktywności ziemi, co może świadczyć o zwiększaniu intensyfikacji produkcji. W grupie gospodarstw o najniższych nakładach materialnych produktywność ziemi była także najniższa i utrzymywała się w poszczególnych latach na zbliżonym poziomie.

2. Społeczna $\mathrm{i}$ ekonomiczna wydajność pracy $\mathrm{w}$ grupie gospodarstw o najwyższych nakładach materialnych była także najwyższa, co świadczy o efektywnym wykorzystaniu zarówno zasobów, jak i nakładów siły roboczej. Różnice między pierwszą i drugą grupa gospodarstw w wypadku ekonomicznej wydajności pracy były mniejsze niż wydajności społecznej. Świadczy to o zbliżonej efektywności nakładów pracy, podczas gdy jej zasoby $\mathrm{w}$ gospodarstwach o najniższych nakładach materialnych były mniej efektywne. Gospodarstwa z drugiej grupy wydajność tą miały nieznacznie wyższą niż z grupy pierwszej.

3. Na ogół najwyższą wielkością rentowności sprzedaży charakteryzowały się gospodarstwa $\mathrm{z}$ drugiej grupy (o przeciętnych nakładach materialnych), podczas gdy z grupy trzeciej rentowność miały najniższą. Może to świadczyć o malejącej efektywności nakładów materialnych wraz $\mathrm{z}$ ich wzrostem o kolejną jednostkę. Jedną $\mathrm{z}$ przyczyn tej tendencji, w zestawieniu z najwyższą dochodowością ziemi w trzeciej grupie gospodarstw, może być korzystanie $\mathrm{w}$ większym stopniu z zakupu materiałów do produkcji, co uniezależnia je od posiadanych zasobów ziemi i zwiększa wartość dochodu rolniczego w skali gospodarstwa. Coraz częściej to kwota dochodu rolniczego z gospodarstwa określa jego możliwości rozwojowe (np. z tytułu posiadanych środków pieniężnych, przyrostu wartości majątku) niż uzyskiwana efektywność jednostkowa, przy małej skali działalności.

\section{Literatura}

ADAMOWSKI Z., 1981: Podstawy ekonomiki i organizacji przedsiębiorstw rolnych. PWRiL, Warszawa.

GOŁAŚ Z., 1999: Struktura i efektywność technik wytwarzania w gospodarstwach indywidualnych makroregionu środkowozachodniego. Roczniki Naukowe SERiA, tom I, zeszyt 1, Kraków.

KIERUL Z., 1986: Ekonomika i organizacja gospodarstw rolniczych. PWRiL, Warszawa.

KLEPACKI B., 2002: Najemna siła robocza a organizacja i wyniki ekonomiczne gospodarstw indywidualnych. Wieś i Rolnictwo, Nr 4 (117), Warszawa. 
MANTEUFFEL R., 1984: Ekonomika i organizacja gospodarstwa rolniczego. PWRiL, Warszawa.

RYCHLIK T. (red.), 1983: Ekonomika rolnictwa. PWRiL, Warszawa.

URBAN M., 1981: Ekonomika i organizacja gospodarstw rolnych. PWN, Warszawa.

WASILEWSKI M., 2003a: Wydajność pracy $w$ indywidualnych gospodarstwach -rolniczych. Roczniki Nauk Rolniczych, Seria G - Ekonomika Rolnictwa, tom 90, zeszyt 2, Wydawnictwo „Wieś Jutra”, Warszawa.

WASILEWSKI M., 2003b: Koncentracja kapitału własnego a wyniki ekonomiczne gospodarstw indywidualnych. [w:] Efektywność źródłem bogactwa narodów. Wydawnictwo AE we Wrocławiu, Wrocław.

WASILEWSKI M., 2004: Zamiany kapitału obcego a wyniki działalności gospodarstw indywidualnych. [w:] Polski przedsiębiorca we współczesnym otoczeniu prawnoekonomicznym. Oficyna Wydawnicza SGH, Warszawa.

Wyniki rachunkowości rolnej gospodarstw indywidualnych 1998, 1999, 2000, 2001. Praca zbiorowa wykonana w Zakładzie Rachunkowości Rolnej IERiGŻ, Wydawnictwo IERiGŻ, Warszawa.

ZIĘTARA W., 2000: Ekonomiczna i społeczna wydajność pracy w rolnictwie i w różnych typach gospodarstw rolniczych. Zeszyty Naukowe SGGW nr 41, Wydawnictwo SGGW, Warszawa.

\section{The Level of Material Outlays and Economic Results of Private Farms}

\section{Abstract}

In the paper the analysis of the relationship between economic results and the level of the material outlays' concentration in private farms is presented. In general, farms with the highest level of the material outlays' concentration were characterized by the highest profitability of land, while in the group of the lowest level of those outlays the profitability was the lowest. In the case of the productivity of land relationships were similar to the case of its profitability. Social and economic efficiency of labour was higher in the group of farms with the highest level of material outlays, what shows that resources and labour outlays were used effectively. In general farms with an average level of material outlays were characterized by the highest profitability of sale, while farms with the highest outlays were characterized by the lowest profitability. It may show that the effectiveness of material outlays decrease with the growth by unit of the level of outlays. One of possible reasons for that tendency, in comparison with the highest profitability of land in the third group of farms, is using purchased materials for the broader scale, what makes farms independent on their resources of land. 
